\title{
Effect of Diet supplementation with Alpha-lipoic acid and brewer's yeast on kidney and liver functions on diabetic rats
}

\author{
Soheir M. El-deab \\ Afif College of Science and Humanities, Shaqra University, Saudi Arabia
}

\begin{abstract}
Alpha-lipoic acid is an ideal antioxidant used in both the treatment and prevention of various oxidative stress related to diseases. This study aims to evaluate the efficiency of alpha-lipoic acid in different doses and their natural animal sources (brewer's yeast) in diabetic rats. Thirty rats weighing approximately $210 \pm 10 \mathrm{~g}$ were divided into five groups after injection with alloxan diabetic rats were fed on a basal diet, alpha-lipoic acid in different doses and $15 \%$ of brewer's yeast. At the end of the experimental period (30 days), the results show that supplementation with 30 and $60 \mathrm{mg} / \mathrm{kg} \mathrm{B} . \mathrm{W} /$ day of alpha-lipoic acid, and $15 \%$ of brewer's yeast caused a significant increase in food intake compared with the positive control group. Data show a significant decrease in the level of blood glucose after supplementation with 30 and $60 \mathrm{mg} / \mathrm{kg}$ B.W/day of alpha-lipoic acid and brewer's yeast as compared with untreated groups, and a positive correlation between increasing the dose of alpha-lipoic acid and decreasing in blood glucose levels. The levels of these parameters of AST, ALT, and ALP increased in diabetic rats while supplemented with alphalipoic acid (30 and $60 \mathrm{mg} / \mathrm{kg} \mathrm{B.W/day)} \mathrm{reduced} \mathrm{significantly} \mathrm{the} \mathrm{levels} \mathrm{of} \mathrm{AST,}$ ALT and ALP, there was a positive correlation between increasing the dose of alpha-lipoic acid and the decreasing effect. Also, brewer's yeast induced the same reduction effect in these enzymes. Significantly decreased in uric acid, urea nitrogen, and creatinine concentrations for diabetic rats, which supplemented with alpha-lipoic acid (30 and $60 \mathrm{mg} / \mathrm{kg} \mathrm{B.W} /$ day). Also, the same resulted observed in the group fed on brewer's yeast. Significant increase in reduced superoxide dismutase (SOD) and glutathione (GSH) after supplementation with 30 and $60 \mathrm{mg} / \mathrm{kg} \mathrm{B.W} /$ day of alpha-lipoic acid for diabetic rats. Brewer's yeast, as sources of alpha-lipoic acid, induced the same effect on GSH, SOD and MDA levels.
\end{abstract}

CONCLUSION: Diet Supplementation with Alpha-lipoic acid, significant decreased the liver and kidney enzyme activities in diabetic rats.

Keywords: alpha-lipoic acid, Brewer's yeast, diabetic rats, kidney, liver 


\section{INTRODUCTION}

Diabetes mellitus is a chronic metabolic disorder characterized by fasting hyperglycemia and plasma glucose levels above defined limits during an oral glucose tolerance test. Besides, it is caused by a total lack of insulin "type 1, insulin-dependent diabetes mellitus" or by insulin resistance in the presence of normal elevated plasma insulin level, decreasing the sensitivity or responsiveness tissue to insulin level "type 2, non-insulin-dependent diabetes mellitus" (Birchtmod et al., 2009). Oxidative stress it observed widely in diabetes. Diabetic patients have increased levels of lipid peroxidation products and decreasing levels of protective antioxidants including ascorbic acid, $\alpha-$ tocopherol, and reduced GSH. (Nourooz et al., 2010 and, Bostecea et al., 2012). Alpha-lipoic acid rapidly stimulates glucose uptake by activating the insulin pathway (Winiarska et al., 2017).

Brewer's yeast contains all the essential amino acids, 14 minerals, and 17 vitamins. It is one of the best natural sources of B-complex vitamins. It is also high in minerals including chromium, zinc, iron, phosphorus, and selenium (Yaworsky et al.,2011). Brewer's yeast considers a good source of RNA, an immune-enhancing nucleic acid that maybe help to prevent degenerative diseases and slowing the process. (Griffith, 2014). Therefore, this research aimed to evaluate the effects of orally given Alpha-lipoic acid on different levels and feeding on brewer's yeast (as an animal source) on liver and kidney functions on diabetic rats.

\section{MATERIAL AND METHODS}

Materials:

Alpha-lipoic acid was purchased from Sigma Chemical Co. (St. Louis, Mo, USA). Cellulose, Alloxan, Casein, Choline chloride, minerals mixture, Dlmethionine, and vitamin mixture obtained from Morgan Co. Cairo, Egypt, and chemical kits used in this study (ALT, ALP, AST, Cr, UN, and uric acid) were purchased from El-Gomhoria Company for chemicals and Drugs, Cairo, Egypt.

\section{Methods:}

\section{Experimental design}

Thirty Sprague -Dawley Strain male albino rats weighing approximately $(310 \pm$ 15 g) used in this study according to Canadian Council on Animal Care 
(1993). All rats fed the control diet (basal diet) according to (Campbell, 1961) for one week. Rats divided into five groups $n=6$ rats with a similar total body. The first group (control negative) fed on the basal diet, second group (control positive) fed on the basal diet, third group (diabetic rats) supplemented with (60mg / alpha-lipoic acid $/ \mathrm{kg}$ B.W/day.), fourth group (diabetic rats) supplemented with (30mg/ alpha-lipoic acid $/ \mathrm{kg}$ B.W/day), Fifth Group (diabetic rats) supplemented with $15 \%$ of brewer's yeast on basal diet .

\section{Induction of experimental diabetes:}

Diabetes millets induced in normal healthy rats via intraperitoneal injection of alloxan $125 \mathrm{mg} / \mathrm{kg}$ body weight according to (Desai and Bhide, 1999). After six hours of injection with alloxan, fasting blood samples were collected to estimate serum glucose. Rats considered diabetic with a fasting blood glucose level above $200 \mathrm{mg} / \mathrm{dl}$ and used in this study.

\section{Biochemical analysis:}

Alkaline phosphatase (ALP), Alanine aminotransferase (ALT), and Aspartate aminotransferase (AST) enzymes measured by the methods described by (Varley et al., 1980 \& Kachmar and Moss., 1976), respectively. The superoxide dismutase (SOD) activity was measured by the method of (Marklund; 1974 \& Croce and Dunn; 2004). Glutathione peroxidase enzyme (GSH) and malonaldehyde ( MDA) were determined according to the methods described by ( Rose; 1997). Serum glucose determined by using chemical kits according to (Trinder, 1969). Creatinine was determined according to the kinetic method (Henry, 1974). Urea determined according to the enzymatic method (Petton and Crouch, 1977). Uric Acid determined by an enzymatic colorimetric test using kits according to (While et al., 1979).

\section{Statistical Analysis:}

The results were analyzed by using the program (SPSS, 2011), version (18). ANOVA test was used to compare results among groups and $\mathrm{P}<0.05$ was considered to be significant (Artimage and Berry, 1987).

\section{Results and Discussion.}

Effect of Diet supplementation with alpha-lipoic acid, brewer's yeast on food intake and body weight gain is present in Table (1). 
The results showed a reduction in body weight gain for diabetic control as compared with control negative group and the mean values were $-21.43 \pm 0.65$ and $+18.93 \pm 1.16 \mathrm{~g}$, respectively. The results of body weight gain indicated that,no significant differences between the effect of treated groups which were supplemented with alpha-lipoic acid at (30\&60 mg $/ \mathrm{kg} \mathrm{B.W/day)} \mathrm{and} \mathrm{brewer's}$ yeast it was significant as compared with diabetic control rats. These data agree well with (Nourooz et al., 2010 ) who reported that Alpha-lipoic acid reduced body weight and increased whole-body energy expenditure.

Table (1): Effect of Diet supplementation with different levels of alpha-lipoic acid, brewer's yeast on food intake and body weight gain (mean+SD).

\begin{tabular}{l|c|c|c|c}
\hline \multicolumn{1}{c|}{ Groups } & $\begin{array}{c}\text { Initial body } \\
\text { weight } \\
(\mathbf{g})\end{array}$ & $\begin{array}{c}\text { Final body } \\
\text { weight }(\mathbf{g})\end{array}$ & $\begin{array}{c}\text { Body weight } \\
\text { gain }(\mathrm{g})\end{array}$ & $\begin{array}{c}\text { Final } \\
\text { intake } \\
(\mathrm{g} / \mathrm{day})\end{array}$ \\
\hline $\begin{array}{l}\text { Control } \\
\text { negative }\end{array}$ & $334.42 \pm 18.47^{\mathrm{a}}$ & $352.35 \pm 19.07^{\mathrm{a}}$ & $+18.93 \pm 1.16^{\mathrm{a}}$ & $18.4 \pm 1.09^{\mathrm{a}}$ \\
\hline Control positive & $335.32 \pm 3.72^{\mathrm{a}}$ & $313.86 \pm 4.28^{\mathrm{b}}$ & $-21.43 \pm 0.65^{\mathrm{b}}$ & $15.6 \pm 0.61^{\mathrm{b}}$ \\
\hline $\begin{array}{l}\text { Diabetic +LA 30 } \\
\text { mg/kg }\end{array}$ & $337.54 \pm 7.07^{\mathrm{a}}$ & $300.30 \pm 5.82^{\mathrm{bc}}$ & $-34.24 \pm 4.47^{\mathrm{c}}$ & $21.1 \pm 1.61^{\mathrm{a}}$ \\
\hline $\begin{array}{l}\text { Diabetic +LA 60 } \\
\text { mg/kg }\end{array}$ & $331.65 \pm 6.03^{\mathrm{a}}$ & $282.03 \pm 1.53^{\mathrm{c}}$ & $-48.62 \pm 5.28^{\mathrm{c}}$ & $23.3 \pm 2.13^{\mathrm{a}}$ \\
\hline Diabetic +BY & $333.76 \pm 7.74^{\mathrm{a}}$ & $301.98 \pm 4.06^{\mathrm{bc}}$ & $-34.78 \pm 3.76^{\mathrm{c}}$ & $20.9 \pm 2.61^{\mathrm{a}}$ \\
\hline LSD & 16.32 & 15.35 & 6.22 & 3.04 \\
\hline
\end{tabular}

(LA) $\alpha$-lipoic acid, (BY) brewer's yeast

$(\mathbf{P}<\mathbf{0 . 0 5})$

Effect of Diet supplementation with alpha-lipoic acid, and brewer's yeast on blood glucose levels in Table (2).

The data illustrated that the level of blood glucose was low in control negative group (healthy rats) as compared with all diabetic groups at zero time. As well as, after two weeks, the experimental diabetic rats supplemented with alpha-lipoic acid at 30 and $60 \mathrm{mg} / \mathrm{kg}$ B.W/day were caused a significant decreased in the levels of blood glucose which the mean values were $217.52 \pm 6.36$ and $205.71 \pm 3.67 \mathrm{mg} / \mathrm{dl}$. Also, there were decreased values of blood glucose in diabetic which treated with brewer's yeast were $247.10 \pm 3.10$ 
$\mathrm{mg} / \mathrm{dl}$. At the end of the experiment, there was a positive correlation between this reduction in the levels of blood glucose and the period of supplementation. The levels of blood glucose in diabetic rats supplemented with alpha-lipoic acid at 30 and $60 \mathrm{mg} / \mathrm{kg} \mathrm{B.W} /$ day, brewer's yeast were $172.58 \pm 2.74,151.12 \pm 2.90$, and $182.55 \pm 3.68 \mathrm{mg} / \mathrm{dl}$, respectively. These results agree well with the data of (Sacob et al., 2015) who demonstrated that alpha-lipoic acid administration in humans with type II diabetes enhanced insulin-stimulated whole-body glucose disposal by about $50 \%$. Winiarska et al., (2017) show that the low doses of alpha-lipoic acid $(10 \mathrm{mg} / \mathrm{kg}$ body weight) did not affect serum glucose concentration. Ferreira et al., (2016) illustrated that a significant decrease in the glucose of serum for diabetic rats administered with $12 \%$ of yeast Saccharomyces.

Table (2):Effect of Diet supplementation with different levels of alpha-lipoic acid, and brewer's yeast on blood glucose levels (mean+SD).

\begin{tabular}{l|c|c|c|c}
\hline \multirow{2}{*}{ Groups } & \multicolumn{4}{c}{ Glucose (mg/dl) } \\
\cline { 2 - 5 } & Zero time & $\begin{array}{c}\text { After 2 } \\
\text { weeks }\end{array}$ & $\begin{array}{c}\text { After 3 } \\
\text { weeks }\end{array}$ & $\begin{array}{c}\text { At the end } \\
\text { of } \\
\text { experiment }\end{array}$ \\
\hline $\begin{array}{l}\text { Control } \\
\text { negative }\end{array}$ & $144.76 \pm 3.52^{\mathrm{b}}$ & $141.34 \pm 4.33^{\mathrm{f}}$ & $142.67 \pm 3.77^{\mathrm{f}}$ & $142.03 \pm 4.79^{\mathrm{f}}$ \\
\hline Control positive & $288.95 \pm 1.24^{\mathrm{a}}$ & $287.35 \pm 5.23^{\mathrm{a}}$ & $284.62 \pm 3.55^{\mathrm{a}}$ & $285.34 \pm 2.57^{\mathrm{a}}$ \\
\hline $\begin{array}{l}\text { Diabetic }+\mathbf{L A} \\
\mathbf{3 0} \mathbf{~ m g / k g}\end{array}$ & $290.74 \pm 1.91^{\mathrm{a}}$ & $217.52 \pm 6.36^{\mathrm{d}}$ & $185.30 \pm 4.76^{\mathrm{d}}$ & $172.58 \pm 2.74^{\mathrm{d}}$ \\
\hline $\begin{array}{l}\text { Diabetic }+\mathbf{L A} \\
\text { 60 mg/kg }\end{array}$ & $288.30 \pm 9.50^{\mathrm{a}}$ & $205.71 \pm 3.67^{\mathrm{c}}$ & $177.36 \pm 5.34^{\mathrm{c}}$ & $151.12 \pm 2.90^{\mathrm{c}}$ \\
\hline Diabetic +BY & $290.26 \pm 5.65^{\mathrm{a}}$ & $246.10 \pm 3.11^{\mathrm{c}}$ & $212.64 \pm 2.78^{\mathrm{c}}$ & $182.55 \pm 3.68^{\mathrm{c}}$ \\
\hline LSD & 8.84 & 7.77 & 6.81 & 5.64 \\
\hline
\end{tabular}

(LA) $\alpha$-lipoic acid, (BY) brewer's yeast

Least significant differences at $\mathbf{P} \leq \mathbf{0 . 0 5}$.

Means with the same letter are insignificantly difference.

Effect of Diet supplementation with alpha-lipoic acid, and brewer's yeast on AST, ALT, and ALP are represented in Table (3). 
Injected rats with alloxan induced elevation in levels of ALT and the value was $42.57 \pm 2.28 \mathrm{U} / \mathrm{L}$ as compared with other groups. Supplemented with 60 $\mathrm{mg} / \mathrm{kg} \mathrm{B}$.W/day of alpha-lipoic acid induced a significant decrease in the levels of ALT compared with diabetic control rats by mean value $22.51 \pm 1.22 \mathrm{U} / \mathrm{L}$. These results agree with Huong and Ide, (2017) who reported that Alpha-lipoic acid has a positive effect in reducing the levels of AST, ALT and ALP in rats.

Table (3): Effect of Diet supplementation with different levels of alpha -lipoic acid, and brewer's yeast on AST, ALT and ALP (mean+SD).

\begin{tabular}{l|c|c|c}
\hline Groups & AST(U/ L) & ALT(U/ L) & ALP(U/ L) \\
\hline Control negative & $57.45 \pm 6.63^{\mathrm{bc}}$ & $32.29 \pm 2.33^{\mathrm{b}}$ & $58.71 \pm 3.67^{\mathrm{b}}$ \\
\hline Control positive & $75.09 \pm 1.62^{\mathrm{a}}$ & $42.57 \pm 2.28^{\mathrm{a}}$ & $68.34 \pm 4.28^{\mathrm{a}}$ \\
\hline $\begin{array}{l}\text { Diabetic +LA 30 } \\
\text { mg/kg }\end{array}$ & $60.35 \pm 2.70^{\mathrm{b}}$ & $28.87 \pm 3.56^{\mathrm{b}}$ & $51.25 \pm 3.85^{\mathrm{c}}$ \\
\hline $\begin{array}{l}\text { Diabetic +LA 60 } \\
\text { mg/kg }\end{array}$ & $46.27 \pm 2.93^{\mathrm{d}}$ & $22.51 \pm 1.22^{\mathrm{c}}$ & $42.91 \pm 3.68^{\mathrm{d}}$ \\
\hline Diabetic +BY & $53.60 \pm 3.73^{\mathrm{bcd}}$ & $31.04 \pm 2.08^{\mathrm{b}}$ & $54.36 \pm 1.36^{\mathrm{bc}}$ \\
\hline LSD & 6.46 & 3.99 & 5.97 \\
\hline
\end{tabular}

(LA) $\alpha$-lipoic acid, (BY) brewer's yeast

Least significant differences at $P \leq 0.05$.

Means with the same letter are insignificantly difference.

Effect of Diet supplementation with alpha-lipoic acid, and brewer's yeast on uric acid, urea nitrogen and creatinine are given in Table (4)

The data revealed that there was a significant increase in uric acid levels for diabetic rats compare with all other treated groups with a value of $5.26 \pm 0.34 \mathrm{mg} / \mathrm{dl}$. After supplementation with alpha-lipoic acid at 30 and 60 $\mathrm{mg} / \mathrm{kg} \mathrm{B.W/day} \mathrm{and} \mathrm{brewer's} \mathrm{yeast,} \mathrm{decrease} \mathrm{the} \mathrm{mean} \mathrm{values} \mathrm{to} 3.76 \pm 0.19$, $2.64 \pm 0.18$, and $4.06 \pm 0.21 \mathrm{mg} / \mathrm{dl}$, respectively as compared with diabetic control rats, the lowest value belonged to the group supplemented with a high dose of alpha-lipoic acid (60 mg/kg B.W/day). Supplementation with alpha-lipoic acid at 30 and $60 \mathrm{mg} / \mathrm{kg} \mathrm{B.W} /$ day, brewer's yeast significantly decreased in the concentration of urea nitrogen as compared with untreated group. As results demonstrated that, the highest value of creatinine levels recorded for diabetic 
control, in which the mean value was $2.07 \pm 0.17 \mathrm{mg} / \mathrm{dl}$. There was a significant decrease in creatinine levels, that appeared, after supplementation with alphalipoic acid at $30 \mathrm{mg} / \mathrm{kg} \mathrm{B.W} /$ day, and brewer's yeast recorded mean values $1.6 \pm 0.22$ and $1.44 \pm 0.08 \mathrm{mg} / \mathrm{dl}$, respectively. The highest reduction, which was $0.94 \pm 0.17 \mathrm{mg} / \mathrm{dl}$, belonged to diabetic group supplemented with alpha-lipoic acid at $60 \mathrm{mg} / \mathrm{kg} \mathrm{B.W/day.} \mathrm{It} \mathrm{could} \mathrm{be} \mathrm{seen} \mathrm{from} \mathrm{the} \mathrm{previous} \mathrm{data} \mathrm{that}$ supplementation with alpha-lipoic acid (especially the high dose) caused a marked decline in uric acid, urea nitrogen, and creatinine levels which increased in diabetic rats. Similarly, earlier reports have shown that alpha-lipoic acid is a naturally occurring that has potent antioxidative activity in a wide variety of experimental systems and clinically used to treat diabetic neuropathy (Biewenga et al., 2015). Also, Winiarska et al., (2017) reported that supplementation with a-lipoic acid decreased the serum urea and creatinine concentrations.

Table (4): Effect of Diet supplementation with different levels of alpha -lipoic acid, and brewer's yeast on uric acid, urea nitrogen and creatinine (mean+SD).

\begin{tabular}{l|c|c|c}
\hline Groups & uric acid (mg/dl) & $\begin{array}{r}\text { urea } \\
\text { nitrogen(mg/dl) }\end{array}$ & Creatinine(mg/dl) \\
\hline Control negative & $3.81 \pm 0.15^{\mathrm{b}}$ & $64.39 \pm 3.96^{\mathrm{b}}$ & $1.56 \pm 0.12^{\mathrm{b}}$ \\
\hline Control positive & $5.26 \pm 0.34^{\mathrm{a}}$ & $71.44 \pm 1.97^{\mathrm{a}}$ & $2.07 \pm 0.17^{\mathrm{a}}$ \\
\hline $\begin{array}{l}\text { Diabetic +LA 30 } \\
\text { mg/kg }\end{array}$ & $3.76 \pm 0.19^{\mathrm{b}}$ & $58.27 \pm 1.50^{\mathrm{c}}$ & $1.6 \pm 0.22^{\mathrm{bc}}$ \\
\hline $\begin{array}{l}\text { Diabetic +LA 60 } \\
\text { mg/kg }\end{array}$ & $2.64 \pm 0.18^{\mathrm{d}}$ & $48.19 \pm 1.63^{\mathrm{d}}$ & $0.94 \pm 0.17^{\mathrm{d}}$ \\
\hline Diabetic +BY & $4.06 \pm 0.21^{\mathrm{b}}$ & $60.45 \pm 2.88^{\mathrm{bc}}$ & $1.44 \pm 0.08^{\mathrm{bc}}$ \\
\hline LSD & 0.36 & 4.19 & 0.27 \\
\hline
\end{tabular}

(LA) $\alpha$-lipoic acid, (BY) brewer's yeast

Least significant differences at $P \leq 0.05$.

Means with the same letter are insignificantly difference.

Effect of Diet supplementation with alpha -lipoic acid, and brewer's yeast on GSH, MDA, and SOD in Table (5).

The data illustrated that there was a significant increase in the levels of Glutathione peroxidase enzyme (GSH) in diabetic groups supplemented with 
alpha-lipoic acid with 30 and $60 \mathrm{mg} / \mathrm{kg}$ B.W/day and brewer's yeast as compared to diabetic group. It could be observed that supplementation with alpha-lipoic acid (especially the high dose) has a positive effect on GSH and The superoxide dismutase (SOD) levels by increasing their levels in diabetic rats, which has the lowest values of them, wherein it decreased : malonaldehyde (MDA) levels as it increased in diabetic rats. Brewer's yeast induced the same effect on GSH, SOD, and MDA. These results agree with (vukkarasu and Anuradha., 2014) found that the activity of SOD enzymatic antioxidants was significantly lowered in fructose-fed rats (has elevation level in blood glucose) meanwhile treatment of fructose-fed rats with alpha-lipoic acid was significantly increased in SOD levels.

Table (5): Effect of Diet supplementation with different levels of alpha -lipoic acid, and brewer's yeast on GSH, MDA, and SOD in diabetic rats (mean+SD).

\begin{tabular}{l|c|c|c}
\hline Groups & GSH (mg/dl) & MDA(n mol/ml) & SOD (unit /ml) \\
\hline Control negative & $32.22 \pm 2.35^{\mathrm{d}}$ & $25.91 \pm 2.21^{\mathrm{b}}$ & $26.42 \pm 4.68^{\mathrm{c}}$ \\
\hline Control positive & $26.48 \pm 1.61^{\mathrm{c}}$ & $31.65 \pm 3.83^{\mathrm{a}}$ & $23.20 \pm 2.27^{\mathrm{d}}$ \\
\hline $\begin{array}{l}\text { Diabetic +LA 30 } \\
\mathbf{m g} / \mathbf{k g}\end{array}$ & $56.23 \pm 2.44^{\mathrm{c}}$ & $22.10 \pm 1.84^{\mathrm{bc}}$ & $36.04 \pm 2.41^{\mathrm{b}}$ \\
\hline $\begin{array}{l}\text { Diabetic +LA 60 } \\
\mathbf{m g} / \mathbf{k g}\end{array}$ & $68.36 \pm 3.18^{\mathrm{a}}$ & $16.44 \pm 0,58^{\mathrm{d}}$ & $44.49 \pm 1.88^{\mathrm{a}}$ \\
\hline Diabetic +BY & $59.04 \pm 2.11^{\mathrm{c}}$ & $22.81 \pm 1.79^{\mathrm{bed}}$ & $35.14 \pm 0.84^{\mathrm{b}}$ \\
\hline LSD & 3.98 & 3.86 & 4.53 \\
\hline
\end{tabular}

(LA) alpha -lipoic acid, (BY) brewer's yeast

(GSH): reduced glutathione.

(MDA): malondialdehyde.

(SOD): superoxide dismutase.

(LA) $\alpha$-lipoic acid, (BY) brewer's yeast

Least significant differences at $\mathbf{P} \leq \mathbf{0 . 0 5}$.

Means with the same letter are insignificantly difference. 


\section{CONCLUSION}

To summarize, in this study; the high doses of alpha-lipoic acid significantly lowered the liver enzymes ALT, AST and ALP activity, it also lowered uric acid, urea nitrogen, and creatinine, but significantly increase in the levels of GSH, and SOD, brewer's yeast give the less effective than high doses of alphalipoic acid. From this study, it can be concluded that alpha-lipoic acid may protect liver and kidney damage in diabetic.

\section{Ethics approval and consent to participate.}

All experiments were carried out according to recommendations of the ethical conditions approved by the Ethics Committee of Ophthalmology Research Center Giza, Egypt, of Experimental Animals, which conformed to the international ethics for handling and care of experimental animals according to the Canadian Council on Animal Care "CCAC" (1993). 


\section{REFFRENCECES}

Artimage,G.Y. and Berry,W.G.(1987).

Statistical Methods 7thEd.Ames, lowa State University Press,39-63.

Biewenga, G. P.; Haenen, G. R. and Bast, A. (2015).

The pharmacology of the antioxidant lipoic acid. Gen Pharmacol, 29: $315-331$.

Birchtmod, B. and Genkins, A. L. (2009).

Fructose and sorbitol in the management of diabetes mellitus. J.

Canad. Diabetic Association, 49: 151 - 159.

Bostecea, H. M. M.; Haenen, G. R. M. M. and Bast, A. (2012).

Inerplay between ascorbic acid, alpha-tocopherol, glutathione and lipoic acid in the protection against microsomal lipid peroxidation. Eur. J. Pharmacol., 183: 436 -437.

Campbell, J. A. (1961). Methodology of protein evaluation. RAG Nutr. Document R. 10Led. 37. Who; June Meeting, New York.

Canadian Council on Animal Care "CCAC" (1993). Guide to the care and use of experimental animals, Ottawa Ontario Canada 1298

Croce, D.C.; Dunn, G. (2004).

Protective effect of lipoic acid against hydrogen peroxide in yeast cells. Toxicol. In Vitro, 17(5-6) : 751-757.

Desai, A. and Bhide, M. (1999).

Hypoglycemic effects of hanitoria suaveolens. Indian J. Med., 81: $86-91$.

Ferreira, I.M.; Pinho, O.; Vieira, E. and Tavarela, J.G. (2016).

Brewer's Saccharomyces yeast biomass: characteristics and potential applications. Trends in Food Science \& Technology. 18.

Griffith, H. (2014).

Winter. Minerals, Supplements \& Vitamins: The Essential Guide. Arizona: Fischer Books.

Henry, R. J. (1974).

Clinical Chemist: Principles and Techniques. 2nd, Edition, Hagerstoun (MD), Harcer, ROW, p. 882.

Huong, D. T. and Ide, T. (2017).

Dietary lipoic acid-on levels of hepatic lipogenic enzymes in rats. British Journal of Nutrition, P. P. $1-9$. 
Kachmar S.; and Moss E.; (1976).

Effect of soymilk and bifidobacterium in aged ovarictomized rats. Bioscience Biotechnology and Biochemistry., 62(9): 16881692.

Marklund, S. (1974).

Involvement of superoxide anion in the auto-oxidation of pyrogallol. Eur J Biochem;47:369- 74.

Nourooz-Zadeh, J.; Rahimi, A. and Tajaddini-Sarmadi, J. (2010).

Relationships between metabolic control and plasma measure of oxidative stress in NIDDM. Diabetologia, 440: 647.

Petton, C. J. and Crouch, S. R. (1977).

Enzymatic Determination of Urea. J. of Anal. Chem., 49:464-468.

Rose, E. A (1997).

Glucosinolates in crop plants. Horticultural Reviews, 19, 99-216.

sacob, S.; Henriksen, E. J.; Tritschler, H. J.; Clancy, D. E.; Simon, I. and schiemann, A. L. et al., (2015).

Thioctic acid enhances glucose-disposal in patients with type 2 diabetes. Horm Metab. Submitted.

SPSS. Statistical packages for the social sciences. 20th ed. Chicago: IBM 2011.

Trinder. J. (1969).

Useing electrochemical detection and high-performance liquid chromatography for determination lipoic acid in plasma. J. Chromatogr., B 672: $274-281$.

Varley, P.; Thilakavathy, T. and Panneerselvam, C. (1980).

Antioxidant lipoate and tissue antioxidant in rats. J. Nutr. Biochem., 11: $122-127$.

vukkarasu, V. and Anuradha, C. V. (2014).

Influence of lipoic acid on lipid peroxidation in blood of insulinresistant rats. Diabetes Obes Metab., 6: 200 - 207.

While, B. A.; Erickson, M. M. and Steven, S. A. C. (1979).

Chemistry for Medical Theologies Ts. 3Rd Ed., C.V. Mosby company saint Louis, USA, P.664.

Winiarska, K.; Malinska, D.; Szymanski, K.; and Bryla, J. (2017).

Lipoic acid ameliorate oxidative stress and renal injury with alloxan in diabetic rabbits. Biochime., pp. $1-10$.

Yaworsky, K.; Somwar, R.; Ramlal, T.; Tritschler, H. J. and Klip, A. (2011).

Engagement of insulin-sensitive in stimulation of glucose transport by alpha-lipoic acid in 3T3-L1 adipocytes. Diabetologia, 43: 290 303. 


\section{الملخص العربي}

تأثير الوجبة المدعمة بحامض الالفا ليبويك وإلخميرة المجففة على وظائف الكبد والكلى فى الفئران المصابة بالسكري

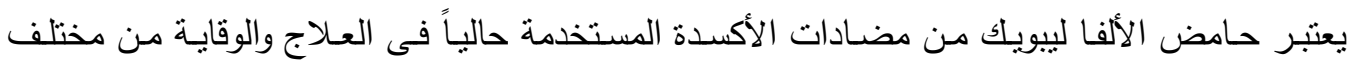
الأمراض المتعلقة بزيادة الثقوق الحرة كالثيخوخة ومرض السكر ، ولذلك تهدف هذاد هذه الدراسة إلى التعرف

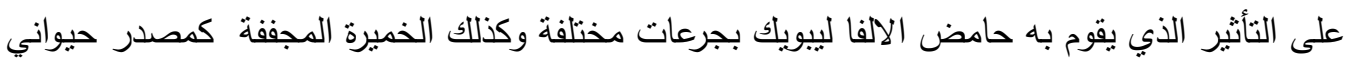

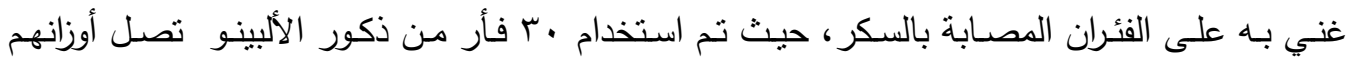

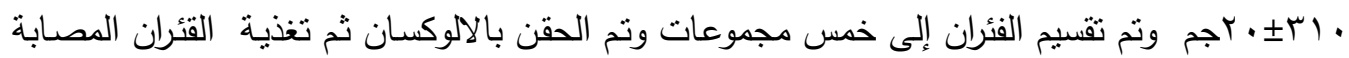

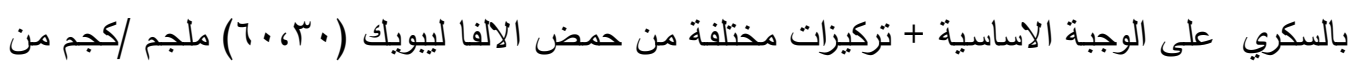

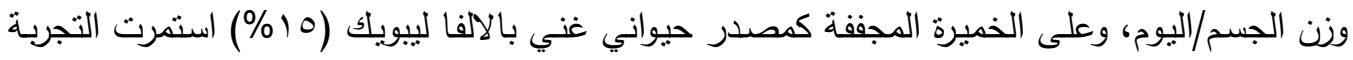

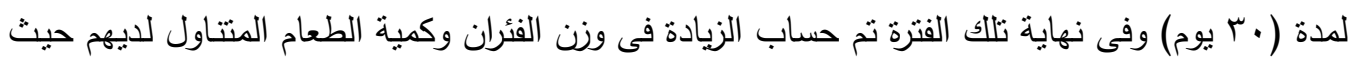

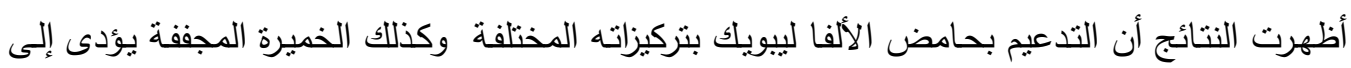

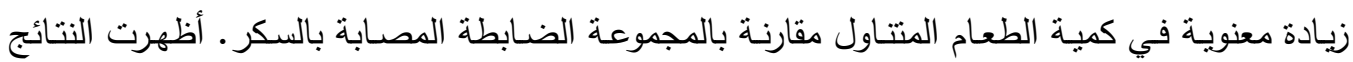
حدوث انخفاض معنوى في مستوى جلوكوز الدم عند الفئران المصابة والمعالجة وكان الانخفاض الاكبر

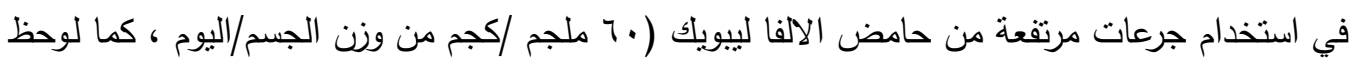

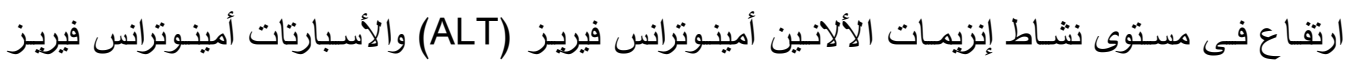

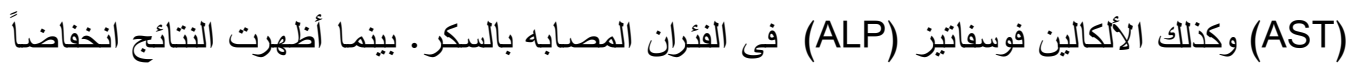

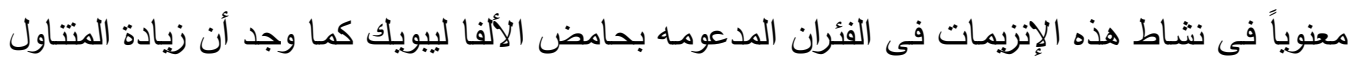

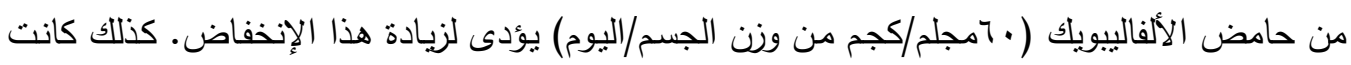

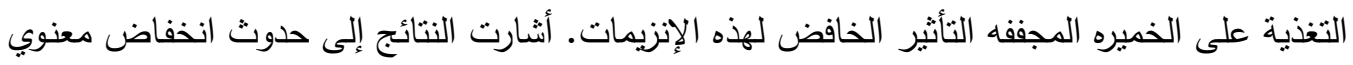

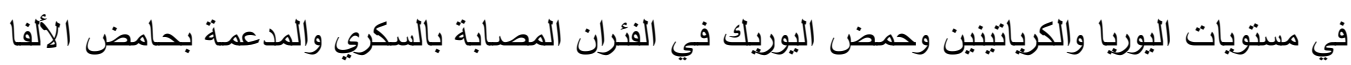
ليبويك (•r و • آملجم/كجم من وزن الجسم/اليوم). كذلك التغذية على الخميره المجففه أظهرت أيضا

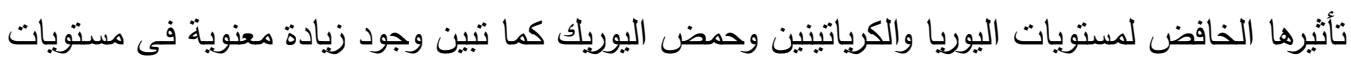

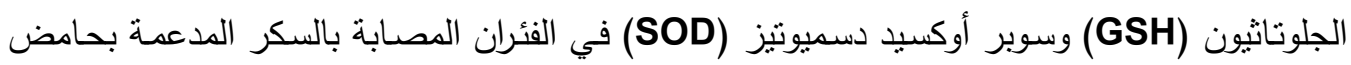

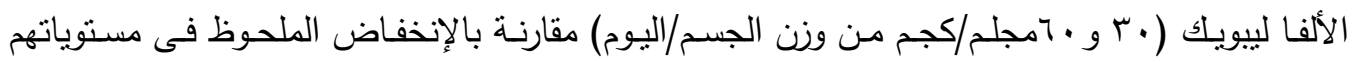

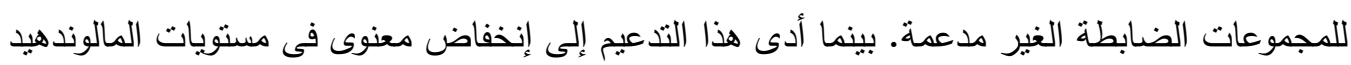
التى كانت فى زيادة ملحوظة فى مجموعات الفئران الضابطة. الخلاصة: أظهرت الوجبة المدعمة بحامض الألفا ليويك أسد انخفاض معنوي في نشاط انزيمات الكبد الكبان والكلي في الفئران المصابة بداء السكري. 